\title{
PERLINDUNGAN HUKUM KONSUMEN ATAS PENERAPAN KLAUSULA BAKU
}

\author{
Kajian Putusan Nomor 26/P.BPSK/12/2014, Nomor 15/PDT.G/2015/PN.SBY, \\ dan Nomor 184 K/PDT.SUS-BPSK/2016
}

\section{LEGAL PROTECTION FOR CONSUMERS IN TERM OF THE IMPLEMENTATION OF STANDARDIZED CLAUSE}

\author{
An Analysis of Court Decision Number 26/P.BPSK/12/2014, \\ Number 15/PDT.G/2015/PN.SBY, and Number 184 K/PDT.SUS-BPSK/2016
}

\author{
M. Syamsudin \& Fera Aditias Ramadani \\ Fakultas Hukum Universitas Islam Indonesia Yogyakarta \\ Jl. Tamansiswa No. 158 Yogyakarta 55151 \\ E-mail:m.syamsudin@uii.ac.id; feraaditiaz@gmail.com
}

Naskah diterima: 12 Oktober 2017; revisi: 27 Maret 2018; disetujui 27 Maret 2018

http://dx.doi.org/10.29123/jy.v11i1.252

\begin{abstract}
ABSTRAK
Kajian ini dilatarbelakangi oleh putusan kasasi Mahkamah Agung yang memutus berbeda dengan putusan Badan Penyelesaian Sengketa Konsumen, yang dikuatkan oleh Pengadilan Negeri Surabaya terkait dengan gugatan pelanggaran klausula baku oleh pelaku usaha jasa kebugaran milik PT X. Permasalahannya adalah: 1) Apakah isi klausula baku yang tercantum dalam perjanjian anggota jasa kebugaran milik PT $\mathrm{X}$ dapat dibenarkan berdasarkan Pasal 18 UndangUndang Perlindungan Konsumen?; 2) Apakah dasar pertimbangan hakim Mahkamah Agung sudah tepat dan mencerminkan nilai-nilai keadilan bagi para pihak jika dibandingkan dengan Putusan Badan Penyelesaian Sengketa Konsumen dan Pengadilan Negeri Surabaya? Kajian ini merupakan penelitian hukum normatif dengan metode pendekatan kasus dan perundangundangan. Hasil kajian menunjukkan bahwa klausula baku dalam perjanjian keanggotaan jasa kebugaran milik PT X telah melanggar ketentuan Pasal 18 ayat (1) huruf a, c, e, f, dan g Undang-Undang Perlindungan
\end{abstract}

Konsumen. Konsekuensinya adalah batal demi hukum. Putusan Mahkamah Agung tidak tepat dan cermat dalam mempertimbangkan fakta-fakta hukum dan penerapan hukumnya. Ditinjau dari substansinya, Putusan Badan Penyelesaian Sengketa Konsumen yang dikuatkan oleh Pengadilan Negeri Surabaya lebih memenuhi rasa keadilan dan melindungi konsumen jika dibandingkan dengan Putusan Mahkamah Agung.

Kata kunci: perlindungan konsumen, klausula baku, perjanjian keanggotaan.

\section{ABSTRACT}

The background of this study is related to the Supreme Court Decision which is contradicted the Decision of the Consumer Dispute Settlement Agency (BPSK) upheld by the Surabaya District Court in relation to the lawsuit regarding the violation of the standard clause by PT $X$. The legal questions are: 1) Does the standardized clause contained in the membership agreement of PT $X$ violate the Article 18 of the Consumer Protection 
Law?; 2) Are the considerations of the Supreme Court Judge appropriate and do they reflect the justice values for the parties when compared with the decision of the Consumer Dispute Settlement Agency and the Surabaya District Court? This study is a normative legal research done with case study and legislation review. The results indicate that the standardized clause in the membership agreement of PT X has violated the provisions of

\section{PENDAHULUAN}

\section{A. Latar Belakang}

Latar belakang kajian Putusan Nomor 184 K/PDT.SUS-BPSK/2016 yang memberikan putusan berbeda dengan putusan tingkat peradilan sebelumnya yaitu Putusan Nomor 26/P. BPSK/12/2014 yang dikuatkan oleh Putusan Nomor 15/PDT.G/2015/PN.SBY. Perbedaan putusan yang dilakukan oleh Mahkamah Agung memiliki pengaruh yang besar mengingat putusan tersebut bersifat final dan mengikat, sehingga menentukan nasib dari masing-masing pihak yang beperkara sebagai upaya hukum yang terakhir.

\section{Putusan Nomor 184 K/PDT.SUS-} BPSK/2016 mengenai keberatan terhadap gugatan pembatalan klausula baku tersebut membatalkan Putusan Nomor 15/PDT.G/2015/ PN.SBY dan menyatakan bahwa Pengadilan Negeri Surabaya telah salah dalam menerapkan hukum serta menyatakan Badan Penyelesaian Sengketa Konsumen Kota Malang tidak berwenang memeriksa dan memutus perkara. Selain itu juga membenarkan tindakan PT X (penggugat kasasi) dengan dikabulkannya gugatan sebagai penyedia jasa tempat kebugaran beserta alatnya untuk mencantumkan klausula baku yang dilarang dalam "Perjanjian Keanggotaan" yang berisi ketentuan dan
Article 18 paragraph (1) letters $a, c, e, f$, and $g$. The consequences is null and void. The Supreme Court failed to consider and employ the legal facts in the ruling. By the content, the Decision of BPSK strengthened by the Surabaya District Court is likely more justifiable and protective compared to the Supreme Court Decision.

Keywords: consumer protection, standardized clause, membership agreement.

persyaratan keanggotaan, pernyataan penolakan tangung jawab atas kehilangan barang milik konsumen serta menolak tanggung jawab atas segala bentuk risiko akibat penggunaan peralatan kebugaran.

PT X merupakan tempat penyedia jasa kebugaran beserta alatnya, yang berkedudukan di Jakarta Selatan. Pada tanggal 28 November 2014 PT X digugat di Badan Penyelesaian Sengketa Konsumen Kota Malang oleh RS, bertempat tinggal di Kota Surabaya dengan gugatan pembatalan penerapan klausula baku yang tercantum dalam perjanjian keanggotaan sebagai syarat pengguna jasa alat kebugaran. RS adalah pengguna jasa (konsumen) tempat kebugaran yang dimiliki oleh PT X, dengan dibuktikan dua buah kartu member anggota yang berlaku seumur hidup dengan total pembayaran Rp35.000.000,dan dikuatkan dengan pengadaan Perjanjian Keanggotaan Nomor GX-10001722 tertanggal 15 November 2008.

Tanggal 29 Oktober 2014 PT X melakukan pemutusan keanggotaan terhadap RS secara sepihak dengan alasan telah melakukan pelanggaran terhadap tata tertib. Selain itu belakangan juga diketahui di dalam ketentuan dan persyaratan keanggotaan serta tata tertib bagi anggota tempat kebugaran milik PT X mengandung klausula-klausula baku yang 
dilarang dalam Pasal 18 Undang-Undang Perlindungan Konsumen. Pihak RS merasa dirugikan dan mengajukan gugatan kepada Badan Penyelesaian Sengketa Konsumen Kota Malang pada tanggal 28 November 2014 dengan gugatan pembatalan terhadap klausula baku dalam perjanjian dan ganti kerugian.

Putusan Nomor 26/P.BPSK/12/2014 tersebut diperkuat dengan Putusan Nomor 15/ PDT.G/2015/PN.SBY, tanggal 21 Mei 2015 yang diajukan oleh pihak yang mengajukan keberatan yaitu PT X namun ditolak. Atas Putusan Nomor 15/PDT.G/2015/PN.SBY tersebut pada tanggal 15 Juni 2015 PT X melakukan keberatan pada tingkat kasasi dan telah diputus dengan Putusan Nomor 184 K/PDT.SUS-BPSK/2016 tanggal 30 Maret 2016 yaitu mengabulkan permohonan kasasi PT X dan membatalkan putusan sebelumnya, dengan alasan bahwa Badan Penyelesaian Sengketa Konsumen Kota Malang tidak berwenang memeriksa dan memutus sengketa tersebut dan menganggap Putusan Nomor 15/PDT.G/2015/PN.SBY telah salah dalam menerapkan hukum.

Persoalan muncul saat terjadi perbedaan putusan hakim yang bertentangan. Dasar pertimbangan hakim dalam memutus perkara menjadi penting untuk menentukan mengenai tepat atau tidaknya suatu putusan. Dalam Putusan Nomor 184 K/PDT.SUS-BPSK/2016, Badan Penyelesaian Sengketa Konsumen Kota Malang dianggap tidak berwenang memeriksa dan memutus sengketa tersebut dengan alasan bahwa gugatan yang diajukan oleh RS (tergugat kasasi) merupakan sengketa ingkar janji (wanprestasi) dan bukan merupakan sengketa konsumen. Dasar pertimbangan hakim adalah Pasal 1 angka 8 Keputusan Menteri Perindustrian Nomor 350/ MPP/Kep/12/2001 tentang Pelaksanaan Tugas dan Wewenang Badan Penyelesaian Sengketa Konsumen, bahwa belum terjadi kerugian di pihak RS (tergugat kasasi) sementara menurut pasal tersebut sengketa konsumen terjadi apabila terdapat kerugian bagi pihak yang melakukan gugatan.

Keberadaan klausula baku dalam perjanjian ketentuan dan persyaratan keangggotaan yang telah dinyatakan dalam Putusan Nomor 26/P.BPSK/12/2014 dan Putusan Nomor 15/PDT.G/2015/PN.SBY sebelumnya melanggar ketentuan Pasal 18 Undang-Undang Perlindungan Konsumen karena mengandung klausula-klausula baku yang dilarang dan jelas merugikan konsumen, seperti penolakan pengembalian uang pembayaran apabila perjanjian batal, melakukan perubahan biaya secara sepihak, melakukan perpanjangan anggota secara otomatis tanpa pemberitahuan, penolakan tanggung jawab atas barang yang hilang atau dicuri serta menolak bertanggung jawab atas segala risiko yang dialami anggota saat menggunakan alat kebugaran.

Keberadaan klausula baku tersebut dibenarkan dan cenderung diabaikan dalam Putusan Nomor 184 K/PDT.SUS-BPSK/2016 dengan pertimbangan bahwa Pengadilan Negeri Surabaya telah salah menerapkan hukum dan membatalkan Putusan Nomor 26/P.BPSK/12/2014 yang diperkuat dengan Putusan Nomor 15/PDT.G/2015/PN.SBY yang sebelumnya menyatakan perjanjian dengan klausula baku tersebut mengandung cacat hukum dan batal demi hukum.

\section{B. Rumusan Masalah}

Mengacu kepada latar belakang, permasalahan dirumuskan sebagai berikut: 
1. Apakah isi klausula baku yang tercantum dalam perjanjian anggota jasa kebugaran milik PT X melanggar Pasal 18 UndangUndang Nomor 8 Tahun 1999 tentang Perlindungan Konsumen?

2. Apakah dasar pertimbangan Putusan Nomor 184 K/PDT.SUS-BPSK/2016 sudah tepat dan mencerminkan keadilan dan melindungi konsumen dibandingkan dengan Putusan Nomor 26/P.BPSK /12/2014 dan Nomor 15/PDT.G/2015/ PN.SBY?

\section{Tujuan dan Kegunaan}

Kajian ini bertujuan untuk menguji isi klausula baku yang tercantum dalam perjanjian anggota jasa kebugaran milik PT X melanggar atau tidak Pasal 18 Undang-Undang Nomor 8 Tahun 1999 tentang Perlindungan Konsumen, dan menganalisis isi Putusan Nomor 26/P. BPSK/12/2014; Putusan Nomor 15/PDT.G/2015/ PN.SBY; dan Putusan Nomor 184 K/PDT.SUSBPSK/2016 sudah mencerminkan keadilan dan melindungi konsumen atau belum. Dengan kajian tersebut diharapkan berguna secara teoretis dan praktis bagi keilmuan hukum terkait dengan hukum perlindungan konsumen.

\section{Tinjauan Pustaka \\ 1. Perjanjian Baku}

Perjanjian dibuat berdasarkan kesepakatan bebas antara kedua pihak yang cakap untuk bertindak (pemenuhan syarat subjektif) untuk melaksanakan suatu prestasi yang tidak bertentangan dengan aturan hukum yang berlaku, kepatutan, kesusilaan, ketertiban umum, serta kebiasaan yang berlaku dalam masyarakat luas (pemenuhan syarat objektif). Namun terkadang kedudukan dari kedua belah pihak tidak seimbang, yang pada akhirnya melahirkan suatu perjanjian yang tidak terlalu menguntungkan bagi salah satu pihak (Barkatullah, 2008: 95). Penerapan suatu perjanjian yang tidak seimbang sehingga menimbulkan keuntungan bagi pelaku usaha sering muncul dalam bentuk perjanjian baku dan/atau klausula baku karena format dan isinya telah ditentukan sebelumnya secara sepihak. Perjanjian seperti ini umumnya dicantumkan dalam setiap dokumen perjanjian yang dibuat oleh salah satu pihak yang lebih dominan dari pihak lainnya. Dikatakan bersifat baku karena baik perjanjian maupun klausula tersebut tidak dapat dan tidak mungkin dinegosiasikan oleh pihak lainnya (Barkatullah, 2008: 96).

Undang-Undang Perlindungan Konsumen memberikan definisi tentang klausula baku dalam Pasal 1 angka 10 yaitu: "Klausula baku adalah setiap aturan atau ketentuan dan syaratsyarat yang telah dipersiapkan dan ditetapkan terlebih dahulu secara sepihak oleh pelaku usaha yang dituangkan dalam suatu dokumen dan/atau perjanjian yang mengikat dan wajib dipenuhi oleh konsumen."

Pengaturan mengenai pencantuman klausula baku dalam Undang-Undang Perlindungan Konsumen dimaksudkan agar kedudukan konsumen setara dengan pelaku usaha berdasarkan prinsip kebebasan berkontrak. Perjanjian baku adalah perjanjian yang isinya dibakukan dan dituangkan dalam bentuk formulir dan hampir seluruh klausulanya dibakukan oleh pemakainya dan pihak lain pada dasarnya tidak mempunyai peluang untuk merundingkan atau meminta perubahan (Kristiyanti, 2009: 139). Seperti yang berlaku bagi setiap konsumen yang akan menggunakan jasa kebugaran yang dimiliki PT X diharuskan melakukan "Perjanjian Keanggotaan" yang berisi klausula baku. 
Perjanjian baku yang berkembang dalam masyarakat memiliki beberapa ciri-ciri antara lain sebagai berikut:

\section{a. Bentuknya tertulis}

Bentuk perjanjian meliputi naskah perjanjian secara keseluruhan dan dokumen bukti perjanjian yang memuat syarat-syarat baku. Kata-kata atau kalimat pernyataan kehendak yang termuat dalam syarat-syarat baku, dibuat secara tertulis berupa akta otentik atau akta di bawah tangan.

b. Formatnya dibakukan

Format perjanjian meliputi model, rumusan, dan ukuran dibakukan, artinya sudah ditentukan model, rumusan, dan ukurannya. Sehingga tidak dapat diganti, dirubah atau dibuat dengan cara lain karena sudah dicetak. Model perjanjian dapat berupa blanko naskah perjanjian lengkap atau blanko formulir yang dilampiri dengan naskah syarat-syarat perjanjian atau dokumen bukti perjanjian yang memuat syarat-syarat baku.

c. Syarat-syaratnya ditentukan oleh pelaku usaha secara sepihak

Syarat-syarat perjanjian yang merupakan pernyataan kehendak ditentukan sendiri secara sepihak oleh pelaku usaha atau organisasi pelaku usaha, karena syaratsyarat perjanjian itu dimonopoli oleh pelaku usaha, maka sifatnya lebih menguntungkan pihak pelaku usaha daripada konsumen. Hal ini tergambar dalam klausula eksonerasi berupa pembebasan tanggung jawab pelaku usaha, tanggung jawab tersebut beralih menjadi beban konsumen. d. Konsumen hanya dapat menerima atau menolak

Jika konsumen menerima syarat-syarat perjanjian yang ditawarkan kepadanya, maka harus menandatangani perjanjian tersebut. Penandatanganan perjanjian tersebut menunjukkan bahwa konsumen bersedia memikul beban tanggung jawab yang seharusnya menjadi kewajiban pelaku usaha. Jika konsumen tidak setuju dengan syarat-syarat perjanjian yang ditawarkan tersebut, ia dapat menolak namun tidak dapat melakukan negosiasi syarat-syarat yang sudah distandarisasikan tersebut.

e. Isinya selalu menguntungkan pelaku usaha Perjanjian baku dirancang secara sepihak oleh pihak pelakuusaha, sehinggaperjanjian yang dibuat dengan cara demikian isinya akan selaku menguntungkan pihak pelaku usaha (Muhammad, 1992: 6).

Perjanjian baku dapat dibedakan menjadi tiga jenis, yaitu:

a. Perjanjian baku sepihak, yaitu perjanjian baku yang isinya ditentukan oleh pihak yang kuat kedudukannya dalam perjanjian tersebut, biasanya oleh pelaku usaha yang kedudukannya lebih kuat;

b. Perjanjian baku yang ditetapkan pemerintah, yaitu perjanjian baku yang mempunyai objek berupa hak-hak atas tanah;

c. Perjanjian baku yang sudah ditentukan di lingkungan notaris atau advokat, yaitu perjanjian yang sejak semula sudah disediakan untuk memenuhi permintaan dari anggota masyarakat yang meminta 
bantuan notaris atau advokat yang bersangkutan (Badrulzaman, 1990: 49).

Penggunaan klausula baku dalam suatu perjanjian dianggap tidak melanggar ketentuanketentuan dalam hukum perdata terutama yang berkaitan dengan asas kebebasan berkontrak. Hal tersebut karena dalam perjajian baku tidak semua isi perjanjian dibakukan hanya saja mengurangi keberadaan asas kebebasan berkontrak.

Konsumen masih diberi kebebasan untuk menentukan mengenai jenis barang, jumlah, warna, tempat, waktu, dan hal-hal lain yang berkaitan dengan objek perjanjian. Sederhananya konsumen masih diberi kebebasan untuk membuat perjanjian dalam hal-hal tertentu yang berkaitan dengan objek perjanjian. Hal yang menjadi masalah adalah terdapat klausula eksonerasi dalam suatu perjanjian baku yang mengalihkan tanggung jawab pelaku usaha.

Klausula eksonerasi adalah syarat yang secara khusus membebaskan pengusaha dari tanggung jawab terhadap akibat yang merugikan, yang timbul dari pelaksanaan perjanjian. Klausula eksonerasi dapat berasal dari rumusan pengusaha secara sepihak, dapat juga berasal dari rumusan pasal undang-undang. Klausula eksonerasi rumusan pengusaha membebankan pembuktian pada konsumen, bahwa konsumen tidak bersalah dan inilah yang menyulitkan konsumen.

Klausula eksonerasi rumusan undangundang membebankan pembuktian pada pengusaha bahwa ia tidak bersalah, sehingga bebas tanggung jawab. Klausula eksonerasi hanya dapat digunakan dalam pelaksanaan perjanjian dengan iktikad baik. Apabila terdapat kerugian yang timbul karena kesengajaan pengusaha maka bertentangan dengan kesusilaan.
Fuady menggunakan istilah klausula eksemsi untuk menyebut klausula eksonerasi. Klasula eksemsi adalah suatu klausula dalam kontrak yang membebaskan atau membatasi tanggung jawab dari salah satu pihak jika terjadi wanprestasi padahal menurut hukum, tanggung jawab tersebut mestinya dibebankan kepadanya. Secara teknis yuridis, klausula eksemsi dalam suatu kontrak biasanya dilakukan melalui tiga metode sebagai berikut:

a. Metode pengurangan atau bahkan penghapusan atas kewajiban-kewajiban hukum yang biasanya dibebankan kepada salah satu pihak;

b. Metode pengurangan atau bahkan penghapusan terhadap akibat hukum karena pelaksanaan kewajiban yang tidak benar;

c. Metode penciptaan kewajiban-kewajiban tertentu kepada salah satu pihak dalam kontrak (Fuady, 2003: 98).

Pasal 18 Undang-Undang Perlindungan Konsumen mengatur larangan pencantuman klausula baku yang menyatakan sebagai berikut:

1) Pelaku usaha dalam menawarkan barang dan/atau jasa yang ditujukan untuk diperdagangkan dilarang membuat atau mencantumkan klausula baku pada setiap dokumen dan/atau perjanjian apabila:

a. Menyatakan pengalihan tanggung jawab pelaku usaha;

b. Menyatakan bahwa pelaku usaha berhak menolak penyerahan kembali barang yang dibeli konsumen;

c. Menyatakan bahwa pelaku usaha berhak menolak penyerahan uang 
yang dibayarkan atas barang atau jasa yang dibeli oleh konsumen;

d. Menyatakan pemberian kuasa dari konsumen kepada pelaku usaha baik secara langsung maupun tidak langsung untuk melakukan segala tindakan sepihak yang berkaitan dengan barang yang dibeli secara angsuran;

e. Mengatur perihal pembuktian atas hilangnya kegunaan barang atau pemanfaatan jasa yang dibeli konsumen;

f. Memberi hak kepada pelaku usaha untuk mengurangi manfaat jasa atau mengurangi harta kekayaan konsumen yang menjadi objek jual beli jasa;

g. Menyatakan tunduknya konsumen kepada peraturan yang berupa aturan baru, tambahan atau lanjutan dan/ atau pengubahan lanjutan yang dibuat secara sepihak oleh pelaku usaha dalam masa konsumen memanfaatkan jasa yang dibelinya;

h. Menyatakan bahwa konsumen memberi kuasa kepada pelaku usaha untuk pembebanan hak tanggungan, hak gadai, hak jaminan terhadap barang yang dibeli oleh konsumen secara angsuran.

2) Pelaku usaha dilarang mencantumkan klausula baku yang letak atau bentuknya sulit terlihat atau tidak dapat dibaca secara jelas, atau yang pengungkapannya sulit dimengerti.
3) Setiap klausula baku yang telah ditetapkan oleh pelaku usaha pada dokumen atau perjanjian yang memenuhi ketentuan sebagaimana dimaksud pada ayat (1) dan ayat (2) dinyatakan batal demi hukum.

4) Pelaku usaha wajib menyesuaikan klausula baku yang bertentangan dengan undangundang ini.

\section{Perlindungan dan Sengketa Konsumen}

Perlindungan hukum terhadap konsumen didasarkan pada adanya sejumlah hak konsumen yang perlu dilindungi dari tindakantindakan yang mungkin merugikan. Hak-hak ini merupakan hak-hak yang sifatnya sangat mendasar dan universal sehinga perlu mendapat jaminan dari negara atas pemenuhannya. Pengertian konsumen secara umum adalah pemakai, pengguna, dan/atau pemanfaat barang dan atau jasa untuk tujuan tertentu (keperluan sendiri dan tidak untuk diperdagangkan kembali) (Barkatullah, 1990: 8).

Berdasarkan Pasal 1 angka (2) UndangUndang Perlindungan Konsumen, konsumen adalah "Setiap orang pemakai barang dan/atau jasa yang tersedia dalam masyarakat, baik bagi kepentingan diri sendiri, keluarga, orang lain, maupun makhluk hidup lain dan tidak untuk diperdagangkan." Dari pengertian tersebut, dapat dilihat bahwa pengertian konsumen yang terdapat di dalam Undang-Undang Perlindungan Konsumen termasuk ke dalam pengertian konsumen akhir, dengan unsur-unsur sebagai berikut:

\section{a. $\quad$ Orang (naturlijk person);}

b. Barang dan/atau jasa atau produk; 
c. Untuk kepentingan diri sendiri, keluarga, orang lain;

d. Tidak untuk diperdagangkan kembali.

Berdasarkan Pasal 1 Undang-Undang Perlindungan Konsumen, perlindungan konsumen adalah segala upaya untuk menjamin adanya kepastian hukum untuk memberikan perlindungan kepada konsumen. Perlindungan konsumen sebagaimana dimaksud adalah segala upaya yang menjamin adanya kepastian hukum dan memberi perlindungan kepada konsumen melalui asas keseimbangan. Hal ini berarti bahwa perlindungan tidak hanya diberikan kepada konsumen, tetapi juga kepada pelaku usaha yang jujur, beriktikad baik dan bertanggung jawab. Bentuk perlindungan yang diberikan UndangUndang Perlindungan Konsumen adalah dengan mengakui, baik hak dan kewajiban konsumen di satu pihak maupun hak dan kewajiban pelaku usaha di lain pihak.

Undang-Undang Perlindungan Konsumen mengatur tanggung jawab pelaku usaha pada Pasal 19 dan 28. Pasal 19, mengatur bahwa:

1) Pelaku usaha bertanggung jawab memberikan ganti rugi atas kerusakan, pencemaran, dan/atau kerugian konsumen akibat mengonsumsi barang dan/atau jasa yang dihasilkan atau diperdagangkan.

2) Ganti rugi sebagaimana dimaksud pada ayat (1) dapat berupa pengembalian uang atau penggantian barang dan/atau jasa yang sejenis atau setara nilainya, atau perawatan kesehatan dan/atau pemberian santunan yang sesuai dengan ketentuan peraturan perundangundangan yang berlaku.

3) Pemberian ganti rugi dilaksanakan dalam tenggang waktu tujuh hari setelah tanggal transaksi.

4) Pemberian ganti rugi sebagaimana dimaksud pada ayat (1) dan ayat (2) tidak menghapuskan kemungkinan adanya tuntutan pidana berdasarkan pembuktian lebih lanjut mengenai adanya unsur kesalahan.

5) Ketentuan sebagaimana dimaksud pada ayat (1) dan ayat (2) tidak berlaku apabila pelaku usaha dapat membuktikan bahwa kesalahan tersebut merupakan kesalahan konsumen.

Suatu sengketa terjadi apabila terdapat perbedaan pandangan antara pihak tertentu. Satu pihak merasa dirugikan hak-haknya oleh pihak yang lain, sedang pihak yang lain tidak merasa demikian. Menurut Nasution sengketa konsumen adalah sengketa antara konsumen dengan pelaku usaha tentang produk barang dan/ atau jasa tertentu.

Menurut Pasal 46 ayat (1) UndangUndang Perlindungan Konsumen, yang dapat melakukan gugatan atas pelanggaran yang dilakukan oleh pelaku usaha adalah kosumen perorangan, sekelompok konsumen, Lembaga Perlindungan Konsumen Swadaya Masyarakat, dan pemerintah.

Objek sengketa haruslah produk konsumen, artinya produk itu merupakan barang dan/atau jasa yang umumnya dipakai, digunakan atau dimanfaatkan bagi memenuhi kepentingan diri, keluarga, dan/atau rumah tangga konsumen. Menurut Pasal 23 Undang-Undang Perlindungan Konsumen, gugatan konsumen dapat diajukan ke Badan Penyelesaian Sengketa Konsumen atau badan peradilan di mana konsumen berdomisili. 
Hal ini mempermudah konsumen dalam hal pengajuan gugatan ke pelaku usaha karena konsumen tidak perlu mencari dan mengajukan gugatan ke daerah pelaku usaha berdomisili.

Sanksi terhadap pelanggaran UndangUndang Perlindungan Konsumen dapat dibagi menjadi dua jenis yaitu sanksi administratif dan sanksi pidana. Pasal 60 ayat (1) Undang-Undang Perlindungan Konsumen menentukan bahwa sanksi administratif yang dapat dijatuhkan oleh Badan Penyelesaian Sengketa Konsumen adalah berupa penetapan ganti rugi paling banyak Rp200.000.000,- kepada pelaku usaha yang melakukan pelanggaran berupa:

a. Tidak dilaksanakannya pemberian ganti rugi oleh pelaku usaha kepada konsumen dalam bentuk pengembalian uang atau penggantian barang dan/atau jasa yang sejenis, maupun perawatan kesehatan atau pemberian santunan atas kerugian yang diderita oleh konsumen (Pasal 19).

b. Terjadinya kerugian sebagai akibat kegiatan produksi iklan yang dilakukan oleh pelaku usaha periklanan (Pasal 20).

c. Pelaku usaha yang tidak dapat menyediakan fasilitas jaminan purna jual, baik dalam bentuk suku cadang maupun pemeliharaannya, serta pemberian jaminan atau garansi yang telah ditetapkan sebelumnya, berlaku juga terhadap pelaku usaha yang memperdagangkan jasa. (Pasal 25 dan Pasal 26).

Sanksi pidana adalah sanksi yang dapat dikenakan dan dijatuhkan oleh pengadilan atas tuntutan jaksa penuntut umum terhadap pelanggaran yang dilakukan pelaku usaha dan/ atau pengurusnya. Sanksi pidana ini terdiri atas: a. Pidana Pokok, berupa:

1) Pelaku usaha yang melanggar ketentuan sebagaimana dimaksud dalam Pasal 8, Pasal 9, Pasal 10, Pasal 13 ayat (2), Pasal 15, Pasal 17 ayat (1) huruf a, huruf $b$, huruf c, huruf e, ayat (2) dan Pasal 18 dipidana dengan pidana penjara paling lama lima tahun atau pidana denda paling banyak Rp2.000.000.000,-

2) dst...

b. Sanksi Pidana Tambahan

1) Ketentuan Pasal 63 UndangUndang Perlindungan Konsumen memungkinkan diberikannya sanksi pidana tambahan di luar sanksi pidana pokok yang dapat dijatuhkan.

\section{Keadilan dalam Putusan Hakim}

Peran hakim sangat menentukan dalam menegakkan hukum dan keadilan melalui putusannya. Hakim harus menelaah terlebih dahulu tentang kebenaran peristiwa yang diajukan kepadanya kemudian memberi penilaian terhadap peristiwa tersebut dan mengaitkannya dengan hukum yang berlaku. Setelah itu hakim baru dapat menjatuhkan putusan terhadap suatu peristiwa.

Pertimbangan hukum hakim dalam putusan merupakan salah satu aspek terpenting dalam menentukan terwujudnya nilai dari suatu putusan yang mengandung keadilan dan kepastian hukum, di samping itu juga mengandung manfaat bagi para pihak yang bersangkutan. Pertimbangan hukum ini penting diketahui oleh pihak-pihak yang beperkara dan hakim yang menilai putusan 
tersebut terutama di tingkat kasasi karena hakim kasasi pada hakikatnya hanya berwenang mengenai pemeriksaan tentang hukumnya (judex juris) (Wardah \& Sutiyoso, 2007: 217).

Hakim dalam menyelesaikan kasus sengketa dari para pencari keadilan sudah saatnya mengubah belenggu paradigma lama, yaitu hukum tidak hanya dipahami dari bentuk teks-teks bunyi pasal undang-undang, tetapi apa yang ada di belakang teks (legal reesening). Sebagaimana pendapat Radbruch yang dikutip Sadjipto bahwa nilai hukum itu bertumpu pada tiga nilai dasar, yaitu kepastian, keadilan, dan kemanfaatan.

Profesional hukum harusnya sampai pada dataran mencari apa filosofi pasal itu, atau mencari apa manfaat pasal itu dibuat bagi manusia, kalau tidak bermanfaat dapat saja pasal itu disimpangi (Jamil, 2008).

Kalau para penegak hukum dalam hal berhukum tidak sampai pada dataran keadilan tetapi hanya mendasarkan pada salah benar berdasarkan kualifikasi hukum yang didasarkan teks-teks bunyi pasal undang-undang, maka hakim sebagai salah satu penegak hukum dan keadilan sering dinyatakan dalam ungkapan hanya sebatas "sebagai corong undang-undang", oleh karenanya peran pengadilan sebagai institusi hukum tempat orang mencari keadilan berubah peran menjadi kantor penerapan undangundang saja, atau dalam istilah yang digunakan Satjipto peradilan perannya menjadi sempit yang terisolasi karena pengadilan tidak lebih dan tidak kurang hanya sebagai corong undang-undang (Rahardjo, 2007: 38).

Jika hakim sangat berpegang teguh pada nilai-nilai ideal hukum maka putusan akan menjadi lebih berkualitas, dalam arti lebih dekat dengan keadilan dan kebenaran. Namun jika terjadi pergeseran pilihan nilai-nilai ideal hukum ke nilai-nilai subjektif akan berimplikasi pada merosotnya kualitas putusan hakim, artinya putusan akan menjauhi nilai keadilan dan kebenaran (Syamsudin, 2011).

Untuk melihat nilai keadilan berupa keadilan subtantif dan keadilan prosedural dalam suatu putusan pengadilan perkara perdata dapat digunakan parameter seperti pada tabel berikut ini:

\section{Tabel 1. Parameter Keadilan dalam Putusan Hakim Perkara Perdata}

\begin{tabular}{|c|c|}
\hline Keadilan Substantif & Keadilan Prosedural \\
\hline - Asumsi Dasar: & - Asumsi Dasar: \\
\hline $\begin{array}{l}\text { Keadilan substantif adalah keadilan yang terkait dengan } \\
\text { isi putusan hakim dalam memeriksa, mengadili, dan } \\
\text { memutus suatu perkara yang harus dibuat berdasarkan } \\
\text { pertimbangan rasionalitas, kejujuran, objektivitas, } \\
\text { tidak memihak (imparsiality), tanpa diskriminasi dan } \\
\text { berdasarkan hati nurani (keyakinan hakim). }\end{array}$ & $\begin{array}{l}\text { Keadilan prosedural adalah keadilan yang terkait dengan } \\
\text { perlindungan hak-hak hukum para pihak penggugat/ } \\
\text { tergugat/pihak yang berkepentingan) dalam setiap } \\
\text { tahapan proses acara di pengadilan. }\end{array}$ \\
\hline - Hasil Pengukuran: & - Hasil Pengukuran: \\
\hline $\begin{array}{l}\text { Jika hasil pengukuran nilainya positif, maka dianggap } \\
\text { memenuhi keadilan substantif, sebaliknya jika hasil } \\
\text { pengukuran nilainya negatif tidak ada keadilan } \\
\text { substantif. }\end{array}$ & $\begin{array}{l}\text { Jika hasil pengukuran nilainya positif, maka dianggap } \\
\text { terdapat keadilan prosedural, sebaliknya jika hasil } \\
\text { pengukuran nilainya negatif maka tidak ada keadilan } \\
\text { prosedural. }\end{array}$ \\
\hline
\end{tabular}


1. Apakah hakim menggunakan yurisprudensi sebagai dasar pertimbangan?

2. Apakah hakim menggunakan sumber hukum berupa doktrin sebagai dasar pertimbangan?

3. Apakah putusan hakim menggunakan sumber berupa nilai-nilai hukum yang hidup dalam masyarakat, yaitu berupa hukum adat, hukum lokal, dan/atau kebiasaan?

4. Apakah amar putusan hakim merupakan kesimpulan yang logis terkait dengan fakta dan hukum?

5. Apakah konklusi dalam putusan hakim ini sudah runtut dan sistematis yang didukung oleh pertimbangan fakta dan hukum, sehingga tidak ada konklusi yang dipaksakan?

6. Dalam menetapkan amar putusan, apakah teridentifikasikan adanya pertimbangan factor-faktor non-yuridis (psikologis, sosial, ekonomi, edukatif, lingkungan, religius)?
1. Apakah putusan hakim sudah memuat hal-hal yang harus ada dalam suatu putusan pengadilan sebagaimana ditetapkan dalam Pasal 2 ayat (1) Undang-Undang Nomor 48 Tahun 2009 dan Pasal $184 \mathrm{HIR} / 195 \mathrm{RBG}$ ?

2. Apakah putusan hakim sudah mencermati alat-alat bukti yang sah sesuai dengan Pasal 164, 153, dan 154 HIR atau 284, 180, dan 181 RBG, yang digunakan di dalam memutuskan perkara?

3. Apakah penerapan hukum pembuktian sesuai dengan perjanjian/undang-undang, doktrin dan/atau yurisprudensi?

4. Apakah hakim sudah memuat secara proporsional antara argumen penggugat dan tergugat di dalam pertimbangannya?

5. Apakah hari/tanggal dilakukan musyawarah majelis hakim pengadilan negeri (dalam pengambilan keputusan) berbeda dengan hari/tanggal putusan diucapkan?

Sumber: Syamsudin (2014)

Hakim merupakan pelaksana inti yang secara fungsional melaksanakan kekuasaan kehakiman. Oleh karena itu, keberadaannya sangat penting dan determinan dalam menegakkan hukum dan keadilan melalui putusan-putusannya (Sutiyoso, 2006: 5).

Dasar-dasar atau alasan yang dirumuskan oleh hakim harus dimuat dalam pertimbangan atau konsideran yang mendukung putusan sebagai pertanggungjawaban kepada masyarakat mengapa ia mengambil putusan demikian sehingga suatu putusan mempunyai nilai objektif (Wardah \& Sutiyoso, 2007:217). Selain itu, hakim juga bertanggung jawab terhadap para pihak, pengadilan yang lebih tinggi dan ilmu hukum sehingga putusan mempunyai wibawa dan bukan karena hakim tertentu yang menjatuhkannya (Mertokusumo, 1990: 5).

\section{METODE}

Jenis penelitian ini tergolong penelitian hukum normatif, yaitu penelitian yang mengkaji hukum sebagai norma dalam bentuk putusan pengadilan dan perundang-undangan. Metode pendekatan yang digunakan adalah pendekatan kasus dan pendekatan perundang-undangan. Pendekatan kasus dilakukan dengan menelaah permasalahan sengketa konsumen antara PT X dengan RS dalam Putusan Nomor 184 K/PDT. SUS-BPSK/2016.

Hal pokok yang dikaji adalah pertimbangan hukum hakim dengan mempertimbangkan putusan tingkat sebelumnya. Sementara itu pendekatan perundang-undangan dilakukan dengan menelaah peraturan perundang-undangan yang berhubungan dengan permasalahan hukum yang sedang dihadapi.

Bahan-bahan hukum yang diperoleh dianalisis secara deskriptif kualitatif. Analisis ini difokuskan pada substansi hukumnya dengan menelaah bahan-bahan hukum yang diperoleh secara sistematis danutuh. Hasiltelaah bahan-bahan 
hukum tersebut didasarkan pada permasalahan yang akan dipecahkan sehingga dihasilkan suatu kesimpulan yang dapat dipergunakan untuk menjawab rumusan masalah yang diajukan.

\section{HASIL DAN PEMBAHASAN}

\section{Analisis Isi Klausula Baku dalam Perjanjian Keanggotaan dan Perjanjian Tambahan Keanggotaan Jasa Kebugaran Milik PT X}

Pelaku usaha dan konsumen secara yuridis sering dinyatakan berkedudukan sama, tetapi faktanya konsumen adalah pihak yang selalu mengikuti kemauan pelaku usaha. Fenomena kontrak-kontrak standar yang banyak beredar di masyarakat merupakan petunjuk yang jelas betapa tidak berdayanya konsumen menghadapi pelaku usaha. Dalam kontrak demikian pelaku usaha dapat dengan sepihak menghilangkan kewajiban yang seharusnya dipikulnya (Shidarta, 2006: 63).

Suatu perjanjian apabila memuat kedudukan para pihak yang tidak seimbang, maka biasanya pihak yang lemah tidak berada dalam keadaan yang betul-betul bebas untuk menentukan apa yang diinginkan dalam perjanjian tersebut. Dalam hal demikian, pihak yang memiliki posisi lebih kuat biasanya menggunakan kesempatan tersebut untuk menentukan klausula-klausula tertentu dalam suatu perjanjian baku, sehingga perjanjian yang seharusnya dibuat atau dirancang oleh para pihak yang terlibat dalam perjanjian, tidak ditemukan lagi dalam perjanjian baku, karena format dan isi perjanjian dirancang oleh pihak yang kedudukannya lebih kuat (Miru \& Yudo, 2014: 114). Oleh karena yang merancang format dan isi perjanjian adalah pihak yang memiliki kedudukan lebih kuat, maka dapat dipastikan perjanjian tersebut memuat klausula-klausula yang menguntungkan baginya, atau meringankan atau menghapuskan beban-beban atau kewajibankewajiban tertentu yang seharusnya menjadi tanggung jawabnya (Miru \& Yudo, 2014:15).

Perjanjian baku merupakan suatu bentuk perjanjian yang secara teoretis masih mengundang perdebatan (Zulham, 2013: 76). Perjanjian yang mengandung klausula baku sebenarnya tidak dilarang oleh undang-undang. Menurut Pasal 18 Undang-Undang Perlindungan Konsumen terdapat larangan mencantumkan klausulaklausula tertentu dalam perjanjian yang bertujuan untuk melindungi konsumen (Miru \& Yudo, 2014: 110). Apabila tetap dicantumkan maka klausula baku itu menjadi batal demi hukum (Shidarta, 2006: 151).

Faktanya klausula baku yang dilarang tersebut hingga saat ini masih dicantumkan oleh pelaku usaha tanpa adanya sanksi yang dikenakan. Hal ini antara lain dipengaruhi oleh sikap konsumen terhadap keberadaan klausula baku, ketaatan pelaku usaha terhadap aturan, dan ketegasan aparatur negara dalam menegakkan aturan dan sanksi (Tobing, 2016).

Peran hakim menjadi sangat penting dan menentukan dalam menyelesaikan sengketa konsumen. Di pundak para hakim telah diletakkan kewajiban dan tanggung jawab agar hukum dan keadilan ditegakkan, baik yang didasarkan pada hukum tertulis maupun hukum tidak tertulis (Siregar, 1983: 7). Namun demikian, setiap hakim memiliki pandangan yang berbeda sehingga banyak ditemui berbagai putusan yang kontroversi. Dalam hal ini, pertimbangan hukum (rechtsgronden) akan menentukan nilai dari suatu putusan hakim sehingga aspek pertimbangan hukum oleh hakim harus disikapi secara teliti, baik, dan cermat. 
RS adalah konsumen pengguna jasa kebugaran yang dimiliki oleh PT X, dengan dibuktikan dua buah kartu member anggota yang berlaku seumur hidup dengan total pembayaran Rp35.000.000,- dan dikuatkan dengan pengadaan Perjanjian Keanggotaan Nomor GX-10001722 tertanggal 15 November 2008. Pada tanggal 29 Oktober 2014 jasa kebugaran yang dimiliki oleh PT X memutus keanggotaan RS secara sepihak dengan dasar telah melanggar ketentuan dalam Perjanjian Keanggotaan, selain itu juga menolak pengembalian sisa uang pembayaran karena perjanjian baru berjalan sekitar enam tahun dengan alasan adanya klausula dalam perjanjian yang menyatakan semua uang yang telah dibayarkan tidak dapat dikembalikan.
Perjanjian keanggotaan tersebut dinyatakan oleh Putusan Nomor 15/PDT.G/2015/PN.SBY yang menguatkan Putusan Nomor 26/P. BPSK/12/2014 telah melanggar ketentuan Pasal 18 Undang-Undang Perlindungan Konsumen. Namun dalam putusan inkrahnya di tingkat kasasi dengan Putusan Nomor 184 K/PDT.SUSBPSK/2016 membatalkan Putusan Nomor 15/ PDT.G/2015/PN.SBY dan Putusan Nomor 26/P. BPSK/12/2014, sehingga putusan kasasi yang bersifat final dan mengikat sebagai upaya hukum yang terakhir merugikan pihak konsumen.

Tabel 2 berikut ini merupakan hasil analisis isi dari klausula-klausula dalam perjanjian keanggotaan jasa kebugaran milik PT X berdasarkan Pasal 18 Undang-Undang Perlindungan Konsumen.

Tabel 2. Analisis Isi Perjanjian Klausula Baku tentang Ketentuan dan Persyaratan Keanggotaan Dikaitkan dengan Pasal 18 Undang-Undang Perlindungan Konsumen

\begin{tabular}{|c|c|c|}
\hline No. & Isi Klausula Baku & Hasil Analisis \\
\hline 1. & $\begin{array}{l}\text { Nomor } 1 \text { menyatakan: "Anda wajib memenuhi } \\
\text { batas usia (18 tahun atau lebih) ketika } \\
\text { menyetujui perjanjian ini. Jasa kebugaran } \\
\text { milik PT X berhak mengubah setiap dan } \\
\text { seluruh peraturan dari waktu ke waktu } \\
\text { sesuai kebijaksanaan kami. Setelah sekali } \\
\text { didaftarkan maka anda setuju bahwa semua } \\
\text { peraturan ini berlaku pada anda." }\end{array}$ & $\begin{array}{l}\text { Ketentuan tersebut bertentangan dengan Pasal } 18 \text { ayat (1) } \\
\text { huruf g yang menyatakan pelaku usaha dilarang "Menyatakan } \\
\text { tunduknya konsumen kepada peraturan yang berupa aturan } \\
\text { baru, tambahan, lanjutan dan/atau pengubahan lanjutan yang } \\
\text { dibuat sepihak oleh pelaku usaha dalam masa konsumen } \\
\text { memanfaatkan jasa yang dibelinya." }\end{array}$ \\
\hline \multirow[t]{2}{*}{2.} & $\begin{array}{l}\text { Nomor } 4 \text { menyatakan: “Jasa kebugaran milik } \\
\text { PT X berhak untuk menaikkan monthty dies } \\
\text { (pembayaran bulanan)/biaya perpanjangan } \\
\text { berdasarkan kebijakan tanpa pemberitahuan } \\
\text { terlebih dahulu." }\end{array}$ & $\begin{array}{l}\text { Ketentuan tersebut bertentangan dengan Pasal } 18 \text { ayat (1) } \\
\text { huruf } \mathrm{f} \text { dan g yang menyatakan pelaku usaha dilarang: } \\
\text { a. Huruf f: "Memberi hak kepada pelaku usaha untuk } \\
\text { mengurangi manfaat jasa atau mengurangi harta } \\
\text { kekayaan konsumen yang menjadi objek jual beli jasa." }\end{array}$ \\
\hline & & $\begin{array}{l}\text { b. Huruf g: "Menyatakan tunduknya konsumen kepada } \\
\text { peraturan yang berupa aturan baru, tambahan, lanjutan } \\
\text { dan/atau pengubahan lanjutan yang dibuat sepihak oleh } \\
\text { pelaku usaha dalam masa konsumen memanfaatkan jasa } \\
\text { yang dibelinya." }\end{array}$ \\
\hline
\end{tabular}


3. Nomor 11 menyatakan: "Biaya keanggotaan dan pembayaran bulanan yang telah dibayarkan tidak dapat dikembalikan terlepas dari jumlah penggunaan nyata ataupun perubahan-perubahan dari fasilitas klub termasuk pengurangan dari luas klub. Perubahan biaya-biaya yang berkaitan dengan hal-hal tersebut dapat dinaikkan melalui pemberitahuan tujuh hari di muka yang akan dikirim ke alamat anda seperti yang tercantum di perjanjian ini atau dapat melalui e-mail atau alamat kantor anda. Semua uang yang telah dibayarkan tidak dapat dikembalikan. Jika salah satu klub kami berhenti beroperasi, keanggotaan anda akan secara otomatis dialihkan ke klub kami yang terdekat."

4. Nomor 12 menyatakan: "Anda tidak boleh membekukan keanggotaan anda kecuali ketika anda dalam bepergian di dalam atau ke luar Indonesia selama lebih dari 30 hari, disertai dengan bukti berupa tiket pesawat atau surat perintah perjalanan yang berhubungan dengan pekerjaan atau sekolah. Selama pembekuan, anda tidak akan dikenakan pembayaran bulanan yang telah ditetapkan, tapi dikenakan holding fee (biaya pembekuan) via auto-pay untuk mempertahankan keanggotaan. Jasa kebugaran milik PT X berhak menaikkan holding fee dari waktu ke waktu."

5. Nomor 14 menyatakan: "Untuk melindungi kepentingan bisnisnya dan demi keselamatan dan pertimbangan para anggota lainnya, Jasa kebugaran milik PT X berhak memutuskan keanggotaan setiap anggota. Alasan pemutusan dapat berupa perilaku yang dianggap tidak pantas, termasuk juga tindakan kekerasan terhadap anggota lain atau staf Jasa kebugaran milik PT X. Semua uang yang telah dibayaran tidak dapat dikembalikan."

6. Nomor 16 menyatakan: "Anda perlu menunjukkan kartu keanggotaan anda untuk masuk ke Jasa kebugaran milik PT X. Jika kartu anda hilang atau dicuri, anda wajib menghubungi klub untuk menerbitkan kembali kartu pengganti. Anda bertanggung jawab atas biaya penggantian kartu, Jasa kebugaran milik PT $X$ berhak untuk menaikkan biaya penggantian kartu dari waktu ke waktu."
Ketentuan tersebut bertentangan dengan Pasal 18 ayat (1) huruf c yang menyatakan pelaku usaha dilarang: "Menyatakan bahwa pelaku usaha berhak menolak penyerahan kembali uang yang dibayarkan atas barang dan/atau jasa yang dibeli oleh konsumen."

Ketentuan tersebut bertentangan dengan Pasal 18 ayat (1) huruf e, f, dan g yang menyatakan pelaku usaha dilarang:

a. Huruf e: "Mengatur perihal pembuktian atas hilangnya kegunaan barang atau pemanfaatan jasa yang dibeli oleh konsumen."

b. Huruf f: "Memberi hak kepada pelaku usaha untuk mengurangi manfaat jasa atau mengurangi harta kekayaan konsumen yang menjadi objek jual beli jasa."

c. Huruf g: "Menyatakan tunduknya konsumen kepada peraturan yang berupa aturan baru, tambahan, lanjutan dan/atau pengubahan lanjutan yang dibuat sepihak oleh pelaku usaha dalam masa konsumen memanfaatkan jasa yang dibelinya."

Ketentuan tersebut bertentangan dengan Pasal 18 ayat (1) hurufc yang menyatakan pelaku usaha dilarang: "Menyatakan bahwa pelaku usaha berhak menolak penyerahan kembali uang yang dibayarkan atas barang dan/atau jasa yang dibeli oleh konsumen."

Ketentuan tersebut bertentangan dengan Pasal 18 ayat (1) huruf $\mathrm{f}$ dan $\mathrm{g}$ yang menyatakan pelaku usaha dilarang:

a. Huruf f: "Memberi hak kepada pelaku usaha untuk mengurangi manfaat jasa atau mengurangi harta kekayaan konsumen yang menjadi objek jual beli jasa."

b. Huruf g: "Menyatakan tunduknya konsumen kepada peraturan yang berupa aturan baru, tambahan, lanjutan dan/atau pengubahan lanjutan yang dibuat sepihak oleh pelaku usaha dalam masa konsumen memanfaatkan jasa yang dibelinya." 
7. Nomor 17 menyatakan: "Satu set handuk (satu handuk besar dan satu handuk kecil) tersedia untuk anda dan tanpa biaya yang hanya dapat digunakan di dalam klub saja. Apabila anggota tidak mengembalikan handuk, kehilangan atau merusak handuk anda akan dikenakan biaya pengganti. Jasa kebugaran milik PT X berhak untuk menaikkan biaya penggantian handuk dari waktu ke waktu."
Ketentuan tersebut bertentangan dengan Pasal 18 ayat (1) huruf $f$ dan $g$ yang menyatakan pelaku usaha dilarang:

a. Huruf f: "Memberi hak kepada pelaku usaha untuk mengurangi manfaat jasa atau mengurangi harta kekayaan konsumen yang menjadi objek jual beli jasa."

b. Huruf g: "Menyatakan tunduknya konsumen kepada peraturan yang berupa aturan baru, tambahan, lanjutan dan/atau pengubahan lanjutan yang dibuat sepihak oleh pelaku usaha dalam masa konsumen memanfaatkan jasa yang dibelinya."

8. Nomor 20 menyatakan: "Kamera atau alat perekam foto/video lainnya termasuk telepon genggam yang memiliki alat perekam seperti yang dimaksud tersebut, dilarang digunakan untuk pengambilan gambar atau rekaman dalam lokasi klub terutama di area tempat ruang ganti. Jasa kebugaran milik PT $\mathbf{X}$ tidak bertanggung jawab atas kehilangan barang di seluruh area klub."
Ketentuan tersebut bertentangan dengan Pasal 18 ayat (1) huruf a yang menyatakan pelaku usaha dilarang "menyatakan pengalihan tanggung jawab pelaku usaha."
Berdasarkan Tabel 2 tersebut dapat diketahui bahwa dalam kutipan klausulaklausula baku tersebut, konsumen harus tunduk pada aturan baru, tambahan, lanjutan dan/atau pengubahan lanjutan yang dibuat oleh pelaku usaha secara sepihak. Hal ini jika dikaitkan dengan Pasal 18 ayat (1) hurufg Undang-Undang Perlindungan Konsumen mengatur mengenai larangan pelaku usaha yang menentukan bahwa: "Menyatakan tunduknya konsumen kepada peraturan yang berupa aturan baru, tambahan, lanjutan dan/atau pengubahan lanjutan yang dibuat sepihak oleh pelaku usaha dalam masa konsumen memanfaatkan jasa yang dibelinya"

Ketentuan tersebut, jika dicermati kutipan klausula baku dalam perjanjian keanggotaan terdapat unsur yang menjelaskan bahwa memberikan kesempatan kepada pelaku usaha untuk membuat aturan baru, tambahan, lanjutan dan/atau pengubahan isi perjanjian secara sepihak. Oleh karena itu dimungkinkan bahwa tindakan sepihak yang dilakukan oleh pelaku usaha menguntungkan baginya dan menghindarkan dari berbagai risiko karena dapat saja dengan aturan baru/tambahan tersebut mengalihkannya kepada konsumen.

Selain itu menaikkan biaya dalam berbagai fasilitas dengan sepihak memungkinkan merugikan pihak konsumen dan mengurangi harta kekayaan konsumen secara nyata, seperti larangan pelaku usaha pada Pasal 18 ayat (1) huruf f Undang-Undang Perlindungan Konsumen yang berbunyi: "Memberi hak kepada pelaku usaha untuk mengurangi manfaat jasa atau mengurangi harta kekayaan konsumen yang menjadi objek jual beli jasa."

Klausula-klausula baku di dalam perjanjian keanggotaan nomor 1, 4, 12, 16, dan 17 telah melanggar ketentuan Pasal 18 ayat (1) huruf $\mathrm{g}$ dan huruf $\mathrm{f}$ Undang-Undang Perlindungan Konsumen. Berdasarkan Tabel 2 dapat diketahui bahwa pada perjanjian keanggotaan nomor 11 dan 14 terdapat klausula: “...pembayaran bulanan/uang yang telah dibayarkan tidak dapat dikembalikan ..." Jika dikaitkan dengan Pasal 18 ayat (1) huruf c yang berbunyi melarang pelaku usaha untuk: "Menyatakan bahwa pelaku usaha berhak menolak penyerahan 
kembali uang yang dibayarkan atas barang dan/ atau jasa yang dibeli oleh konsumen." Oleh karena itu jika dicermati dalam Pasal 18 ayat (1) huruf c, pelaku usaha dilarang menolak pengembalian uang/pembayaran yang dilakukan oleh konsumen apabila perjanjian dibatalkan, tidak sesuai dengan yang diperjanjikan dan/atau sebab lain yang dibenarkan. Diketahui bahwa dalam perjanjian keanggotaan nomor 11 dan 14 terdapat klausula yang dilarang dalam Pasal 18 ayat (1) huruf c. Dengan demikian perbuatan pelaku usaha dalam nomor 11 dan 12 telah melanggar ketentan Pasal 18 ayat (1) huruf c Undang-Undang Perlindungan Konsumen. yang menyatakan bahwa pelaku usaha dilarang "menyatakan pengalihan tanggung jawab pelaku usaha."

Dengan demikian klausula perjanjian nomor 20 telah melanggar ketentuan Pasal 18 ayat (1) huruf a Undang-Undang Perlindungan Konsumen. Selain perjanjian keanggotaan, jasa kebugaran milikPTXjuga melakukaan perjanjian tambahan kepada para calon anggotanya yang melanggar ketentuan Pasal 18 ayat (1) UndangUndang Perlindungan Konsumen sebagaimana terdapat dalam Tabel 3 berikut ini:

Berdasarkan Tabel 3 tersebut dapat

Tabel 3. Analisis Isi Perjanjian Keanggotaan Tambahan tentang Pernyataan Penolakan Tanggung Jawab dikaitkan dengan Pasal 18 Undang-Undang Perlindungan Konsumen

\begin{tabular}{|c|c|c|}
\hline No. & Isi Klausula Baku & Hasil Analisis \\
\hline 1. & $\begin{array}{l}\text { Nomor } 1 \text { menyatakan: "Selama latihan, setiap anggota berhak } \\
\text { menggunakan loker harian untuk menyimpan barang-barangnya. } \\
\text { Dengan menandatangani perjanjian ini anda setuju bahwa jasa } \\
\text { kebugaran milik PT X tidak bertanggung jawab atas barang- } \\
\text { barang yang hilang atau dicuri dari loker harian dan/atau loker } \\
\text { sepatu dengan alasan apapun. Anda bertanggung jawab untuk menjaga } \\
\text { keamanan barang-barang pribadi anda di tempat." }\end{array}$ & $\begin{array}{l}\text { Ketentuan tersebut bertentangan } \\
\text { dengan Pasal } 18 \text { ayat (1) huruf a } \\
\text { yang menyatakan pelaku usaha } \\
\text { dilarang "menyatakan pengalihan } \\
\text { tanggung jawab pelaku usaha." }\end{array}$ \\
\hline \multirow[t]{2}{*}{2.} & $\begin{array}{l}\text { Nomor } 2 \text { menyatakan: "Penggunaan fasilitas di jasa kebugaran milik PT } \\
\mathrm{X} \text { tentunya mengandung risiko kecelakaan bagi setiap anggota sendiri, } \\
\text { atau anggota lainnya atau orang lain di sekitarnya, baik disebabkan } \\
\text { oleh anggota maupun oleh orang lain. Jika ada tuntutan dari siapa pun } \\
\text { juga yang dikarenakan oleh cedera apapun, kehilangan atau kerusakan } \\
\text { lainnya yang berkaitan dengan anda atau tamu anda, maka anda } \\
\text { menyetujui untuk: }\end{array}$ & $\begin{array}{l}\text { Ketentuan tersebut bertentangan } \\
\text { dengan Pasal } 18 \text { ayat (1) huruf a dan } \\
\text { g yang menyatakan pelaku usaha } \\
\text { dilarang: } \\
\text { a. Huruf a: "Menyatakan } \\
\text { pengalihan tanggung jawab } \\
\text { pelaku usaha." }\end{array}$ \\
\hline & $\begin{array}{l}\text { i. Membela jasa kebugaran milik PT } \mathbf{X} \text { atas segala tuntutan } \\
\text { tersebut dan membayar jasa kebugaran milik PT } \mathbf{X} \text { atas segala } \\
\text { pengeluaran termasuk biaya hukum berkaitan dengan tuntutan } \\
\text { tersebut. } \\
\text { ii. Melindungi jasa kebugaran milik PT X dari segala tanggung } \\
\text { jawab kepada anda, suami/istri anda, anak dalam kandungan, } \\
\text { keluarga, atau siapapun juga, sebagai akibat yang terkait dari } \\
\text { tuntutan tersebut." }\end{array}$ & $\begin{array}{l}\text { b. Huruf g: "Menyatakan } \\
\text { tunduknya konsumen kepada } \\
\text { peraturan yang berupa aturan } \\
\text { baru, tambahan, lanjutan dan/ } \\
\text { atau pengubahan lanjutan yang } \\
\text { dibuat sepihak oleh pelaku } \\
\text { usaha dalam masa konsumen } \\
\text { memanfaatkan jasa yang } \\
\text { dibelinya." }\end{array}$ \\
\hline
\end{tabular}

Berdasarkan Tabel 2 diketahui juga bahwa dalam perjanjian keanggotaan nomor 20 terdapat klausula: “... tidak bertanggung jawab atas kehilangan barang di seluruh area klub..." Jika dikaitkan dengan Pasal 18 ayat (1) huruf a diketahui bahwa keberadaan klausula baku dalam perjanjian keanggotaaan dan perjanjian tambahan keanggotaan jasa kebugaran milik PT X, jika ditinjau dari Pasal 18 UndangUndang Perlindungan Konsumen, klausula pada 
perjanjian baku tersebut melanggar ketentuan Pasal 18 ayat (1) huruf a, c, e, f, dan g, sehingga akibat hukumnya menurut Pasal 18 ayat (3) yang menentukan bahwa "setiap klausula baku yang telah ditetapkan oleh pelaku usaha pada dokumen atau perjanjian yang memenuhi ketentuan sebagaimana dimaksud pada ayat (1) dan (2) dinyatakan batal demi hukum."

$$
\text { Klausula baku dalam perjanjian }
$$
keanggotaaan dan perjanjian tambahan keanggotaan jasa kebugaran milik PT X menurut Pasal Pasal 18 ayat (3) dianggap batal demi hukum. Hal yang dianggap batal adalah klausula bakunya, sehingga seharusnya jasa kebugaran milik PT X melakukan penyesuaian klausula baku yang bertentangan dengan Pasal 18 ayat (1) Undang-Undang Perlindungan Konsumen, seperti yang disebutkan dalam Pasal 18 ayat (4) yang berbunyi: "Pelaku usaha wajib menyesuaikan klausula baku yang bertentangan dengan undangundang ini."

Ditinjau dari hukum perdata memang mengenal adanya asas kebebasan berkontrak yang terdapat pada Pasal 1338 KUHPerdata ayat (1) yang berbunyi: "Semua perjanjian yang dibuat secara sah berlaku sebagai undangundang bagi mereka yang membuatnya." Meskipun dalam perjanjian berlaku asas kebebasan berkontrak, perlu diingat bahwa pada Pasal 1337 KUHPerdata menyatakan bahwa suatu sebab adalah terlarang, apabila dilarang oleh undang-undang, atau apabila berlawanan dengan kesusilaan baik atau ketertiban umum. Hal tersebut merupakan penegasan kembali akan sifat kebebasan berkontrak yang diatur pada Pasal 1338 ayat (1) KUHPerdata. Oleh karena itu keberadaan asas kebebasan berkontrak tidak berlaku secara mutlak, namun terdapat batasanbatasan dalam hal-hal tertentu.
Pasal 1320 KUHPerdata dapat ditarik kesimpulan bahwa klausula baku pada perjanjian seperti halnya suatu perjanjian pada umumnya harus memenuhi baik syarat-syarat objektif maupun syarat-syarat subjektif dari sahnya suatu perjanjian serta memenuhi asas kebebasan berkontrak, asas konsensualisme serta kedudukan yang seimbang dari para pihak yang membuat perjanjian.

Jika salah satu syarat objektif dari sahnya perjanjian tidak terpenuhi maka perjanjian tersebut adalah batal demi hukum, yang berarti bahwa perjanjian tersebut dianggap tidak pernah ada sejak semula dan tidak mempunyai daya ikat. Artinya, perjanjian sewa menyewa alat kebugaran dengan menggunakan perjanjian keanggotaan jasa kebugaran milik PT X telah melanggar ketentuan Pasal 18 ayat (1) huruf a, c, e, f, dan $\mathrm{g}$, maka perjanjian tersebut batal demi hukum sebagaimana disebutkan dalam Pasal 18 ayat (3). Pasal 18 ayat (4) Undang-Undang Perlindungan Konsumen selanjutnya mewajibkan para pelaku usaha untuk menyesuaikan klausula dalam perjanjian yang bertentangan dengan Pasal 18 Undang-Undang Perlindungan Konsumen ini (Widjaja \& Yani, 2000: 57).

\section{Analisis Pertimbangan Putusan Nomor 184 K/PDT.SUS-BPSK/2016}

Hakim memiliki peran penting dalam menegakkan hukum dan keadilan melalui putusannya. Dalam memberikan putusan, hakim lazimnya menelaah terlebih dahulu tentang kebenaran peristiwa yang diajukan kepadanya kemudian memberi penilaian terhadap peristiwa tersebut dan menggabungkannya dengan hukum yang berlaku. Pertimbangan hukum hakim dalam putusan merupakan salah satu aspek 
terpenting dalam menentukan terwujudnya nilai dari suatu putusan yang mengandung keadilan dan kepastian hukum, di samping itu juga mengandung manfaat bagi para pihak yang bersangkutan.

Pertimbangan hukum ini penting terutama dalam tingkat kasasi karena hakim kasasi pada hakikatnya hanya berwenang mengenai pemeriksaan tentang hukumnya (judex Juris) (Wardah \& Sutiyoso, 2007: 217). Hakim di tingkat kasasi memiliki peran yang sangat penting karena putusannya bersifat final dan mengikat sebagai upaya hukum terakhir, sehingga sangat berpengaruh terhadap nasib para pihak yang beperkara.

Putusan Nomor 184 K/PDT.SUSBPSK/2016 memberikan pertimbangan hukum yang intinya bahwa dari keberatan kasasi yang diajukan oleh pemohon kasasi (PT X), majelis hakim berpendapat bahwa judex facti telah salah menerapkan hukum dengan pertimbangan bahwa pokok perkara yang diperiksa dan diputus oleh Badan Penyelesaian Sengketa Konsumen adalah mengenai tindakan termohon keberatan/ termohon kasasi yang tidak memenuhi persyaratan keanggotaan sebagaimana dimaksud dalam perjanjian keanggotaan, sehingga merupakan sengketa ingkar janji bukan sengketa konsumen, maka Badan Penyelesaian Sengketa Konsumen tidak berwenang memeriksa dan memutus perkara. Oleh karena itu, majelis hakim mengabulkan permohonan kasasi dari pemohon kasasi PT X tersebut dan membatalkan Putusan Nomor 15/PDT.G/2015/PN.SBY yang menguatkan Putusan Nomor 26/P. BPSK/12/2014.

Mahkamah Agung berpendapat bahwa sengketa antara PT X dengan RS merupakan sengketa ingkar janji (wanprestasi) dengan dasar Pasal 1 angka 8 Keputusan Menteri Perindustrian Nomor 350/MPP/Kep/12/2001 tentang Pelaksanaan Tugas dan Wewenang BPSK, yang menentukan bahwa: "Sengketa konsumen adalah sengketa antara pelaku usaha dengan konsumen yang menuntut ganti rugi atas kerusakan, pencemaran dan/atau yang menderita kerugian akibat mengonsumsi barang dan/atau memanfaatkan jasa."

Mahkamah Agung membenarkan keberatan/gugatan kasasi PT X bahwa belum terjadi kerugian pada termohon kasasi (RS), sehingga gugatan Badan Penyelesaian Sengketa Konsumen yang mempersoalkan Pasal 18 Undang-Undang Perlindungan Konsumen tidak tepat dan kabur karena bukan termasuk kewenangan Badan Penyelesaian Sengketa Konsumen dan Pengadilan Negeri Surabaya telah salah dalam menerapkan hukum. Namun apabila dicermati bahwa gugatan RS berawal karena pemutusan anggota secara sepihak sebagai pengguna jasa kebugaran milik PT X tanpa pengembalian sisa uang pembayaran dan menggugat agar klausula baku yang dianggap merugikan pihaknya sebagai konsumen untuk dibatalkan.

$$
\text { Penolakan pengembalian uang }
$$
pembayaran didasarkan pada perjanjian keanggotaan nomor 11 dan 14 dengan klausula “...semua uang yang telah dibayaran tidak dapat dikembalikan..." Keberadaan klausula tersebut telah nyata terbukti melanggar ketentuan Pasal 18 ayat (1) huruf c, sehingga batal demi hukum. Pihak RS sebagai konsumen telah dirugikan karena pemutusan keanggotaan secara sepihak tanpa adanya pengembalian sisa uang pembayaran sebesar Rp35.000.000,- untuk seumur hidup, namun baru berjalan sekitar 
enam tahun keanggotaannya diputus, sehingga sebagai konsumen jelas dirugikan, selain itu terdapat klausula-klausula dalam perjanjian subtantif dalam putusan sebagaimana pada Tabel 4 berikut ini:

Tabel 4. Hasil Pengukuran Keadilan Subtantif pada Putusan Nomor 184 K/PDT.SUS-BPSK/2016

\begin{tabular}{|c|c|c|}
\hline No. & Parameter & Temuan dalam Isi Putusan \\
\hline 1. & $\begin{array}{l}\text { Fakta-fakta hukum yang terungkap di } \\
\text { persidangan. }\end{array}$ & $\begin{array}{l}\text { Majelis hakim dalam pertimbangan hukumnya kurang } \\
\text { mempertimbangkan fakta-fakta hukum secara lengkap dan } \\
\text { hanya mempertimbangkan satu pertimbangan hukum dari } \\
\text { pemohon kasasi. }\end{array}$ \\
\hline 2. & Dasar hukum yang digunakan. & $\begin{array}{l}\text { Majelis hakim hanya menggunakan dasar hukum berupa } \\
\text { Pasal } 1 \text { angka } 8 \text { Keputusan Menperindag Nomor 350/MPP/ } \\
\text { Kep/12/2001 tentang Pelaksanaan Tugas dan Wewenang } \\
\text { Badan Penyelesian Ssengketa Konsumen, tanpa menggunakan } \\
\text { dasar hukum lain yang dapat memperkuat putusan. }\end{array}$ \\
\hline 3. & $\begin{array}{l}\text { Ada tidaknya yurisprudensi yang dijadikan } \\
\text { acuan. }\end{array}$ & $\begin{array}{l}\text { Majelis hakim tidak menggunakan dasar yurisprudensi dalam } \\
\text { membuat pertimbangan hukum. }\end{array}$ \\
\hline 4. & $\begin{array}{l}\text { Ada tidaknya doktrin atau teori-teori hukum } \\
\text { yang dijadikan referensi. }\end{array}$ & $\begin{array}{l}\text { Tidak ada doktrin atau teori yang dijadikan dasar pertimbangan } \\
\text { hukum oleh majelis hakim, sehingga pertimbangannya sangat } \\
\text { kering. }\end{array}$ \\
\hline 5. & $\begin{array}{l}\text { Ada tidaknya hakim menggali nilai-nilai } \\
\text { hukum yang hidup di masyarakat. }\end{array}$ & $\begin{array}{l}\text { Tidak ditemukan mejelis hakim menggali nilai-nilai hukum } \\
\text { yang hidup di masyarakat dalam membuat pertimbangan } \\
\text { hukum. }\end{array}$ \\
\hline 6. & $\begin{array}{l}\text { Logis tidaknya dasar pertimbangan dengan } \\
\text { putusan yang dijatuhkan. }\end{array}$ & $\begin{array}{l}\text { Pertimbangan hukum belum sepenuhnya menunjukkan hal } \\
\text { yang logis karena dalam pembuktian kurang menggunakan } \\
\text { dasar pertimbangan hukum yang kuat dan kurang menggali } \\
\text { fakta-fakta hukum secara cermat. }\end{array}$ \\
\hline
\end{tabular}

keanggotaan yang melanggar ketentuan Pasal 18 Undang-Undang Perlindungan Konsumen. Oleh karena itu pertimbangan majelis hakim kurang cermat karena hanya mempertimbangkan keberatan pemohon kasasi (PT X) dan kurang mempertimbangkan fakta hukum mengenai kerugian yang nyata terjadi pada pihak RS. Meskipun begitu, Putusan Nomor 184 K/PDT. SUS-BPSK/2016 telah memberikan kepastian hukum bagi para pihak.

Dilihat dari substansinya, Putusan Nomor 184 K/PDT.SUS-BPSK/2016 belum mencerminkan keadilan substantif dan kemanfaatan terutama bagi pihak konsumen. Untuk mengukur keadilan substantif tersebut, berikut dipaparkan enam parameter keadilan
Dengantidakdipenuhinyabeberapaparameter keadilan subtantif pada isi Putusan Nomor $184 \mathrm{~K} /$ PDT.SUS-BPSK/2016 tersebut, maka putusan itu dapat dibilang kurang mencerminkan keadilan bagi para pihak terutama konsumen sebagai pihak yang dikalahkan. Hal ini akan nampak kontras jika dibandingkan dengan Putusan Nomor 15/ PDT.G/2015/PN.SBY dan Putusan Nomor 26/P. BPSK/12/2014 sebagai putusan yang dibatalkan. Hasil analisis kedua putusan tersebut dapat dilihat pada Tabel 5 berikut ini:

Berdasarkan Tabel 5 tersebut, dapat diketahui bahwa Putusan Nomor 15/ PDT.G/2015/PN.SBY dan Putusan Nomor 26/P. BPSK/12/2014 lebih mencerminkan keadilan substantif dan perlindungan terhadap konsumen 
Tabel 5. Analisis Keadilan Subtantif pada Putusan Nomor 15/PDT.G/2015/PN.SBY dan Putusan Nomor 26/P.BPSK/12/2014

\begin{tabular}{cll} 
No. & \multicolumn{1}{c}{ Parameter } & \multicolumn{1}{c}{ Temuan dalam Isi Putusan } \\
\hline 1. & $\begin{array}{l}\text { Fakta-fakta hukum yang terungkap di } \\
\text { persidangan. }\end{array}$ & $\begin{array}{l}\text { Majelis hakim dalam pertimbangan hukumna telah menggali } \\
\text { fakta-fakta hukum dalam persidangan berupa alat-alat bukti, } \\
\text { keterangan para pihak, dan keterangan para saksi secara } \\
\text { memadai. }\end{array}$ \\
\hline 2. & Dasar hukum yang digunakan. & $\begin{array}{l}\text { Majelis hakim menggunakan dasar hukum berupa beberapa } \\
\text { peraturan perundang-undang yang terkait. }\end{array}$ \\
\hline 3. & $\begin{array}{l}\text { Ada tidaknya yurisprudensi yang } \\
\text { dijadikan acuan. }\end{array}$ & $\begin{array}{l}\text { Tidak ada dasar yurisprudensi yang diacu oleh majelis hakim } \\
\text { dalam membuat pertimbangan hukum. }\end{array}$ \\
\hline 4. & $\begin{array}{l}\text { Ada tidaknya doktrin atau teori-teori } \\
\text { hukum yang dijadikan referensi. }\end{array}$ & $\begin{array}{l}\text { Tidak ada doktrin atau teori yang dijadikan dasar pertimbangan } \\
\text { hukum oleh majelis hakim. }\end{array}$ \\
\hline 5. & $\begin{array}{l}\text { Ada tidaknya hakim menggali nilai-nilai } \\
\text { hukum yang hidup di masyarakat. }\end{array}$ & $\begin{array}{l}\text { Tidak ditemukan majelis hakim menggali nilai-nilai hukum yang } \\
\text { hidup di masyarakat dalam membuat pertimbangan hukum. }\end{array}$ \\
\hline 6. & $\begin{array}{l}\text { Logis tidaknya dasar pertimbangan } \\
\text { dengan putusan yang dijatuhkan. }\end{array}$ & $\begin{array}{l}\text { Pertimbangan hukum sudah menunjukkan hal yang logis, karena } \\
\text { telah menggabungkan antara fakta-fakta hukum yang terungkap } \\
\text { di persidangan dengan peraturan perundang-undangan yang } \\
\text { berkaitan. }\end{array}$ \\
\hline
\end{tabular}

jika dibandingkan dengan Putusan Nomor 184 K/PDT.SUS-BPSK/2016 karena lebih banyak parameter keadilan yang terpenuhi. Majelis hakim Putusan Nomor 184 K/PDT.SUS-BPSK/2016 dalam membuat pertimbangan hukum kurang cermat sehingga putusan yang dihasilkan tidak melindungi konsumen sebagai pihak yang dirugikan dan posisinya lemah.

Majelis hakim Putusan Nomor 184 K/PDT. SUS-BPSK/2016 seharusnya mempertimbangkan dampak yang muncul dari dibuatnya putusan ini terhadap perlindungan konsumen sebagai pihak yang lemah berhadapan dengan pelaku usaha. Majelis hakim seharusnya tidak hanya mempertimbangkan dari sisi formal kewenangan Badan Penyelesaian Sengketa Konsumen dalam memeriksa sengketa konsumen sebagaimana diatur oleh Pasal 1 angka 8 Keputusan Menteri Perindustrian Nomor 350/MPP/Kep/12/2001, sehingga putusannya menganggap bahwa sengketa tersebut bukan sebagai sengketa konsumen yang menjadi kewenangan Badan Penyelesaian Sengketa Konsumen. Jika hanya sisi tersebut maka putusan kasasi menjadi kurang bermakna dilihat dari aspek perlindungan konsumen.

\section{KESIMPULAN}

Berdasarkan hasil pembahasan diperoleh simpulan sebagai berikut:

1. Isi klausula baku dalam perjanjian keanggotaan jasa kebugaran milik PT X telah melanggar ketentuan Pasal 18 ayat (1) huruf a, c, e, f, dan g. Konsekuensinya adalah batal demi hukum. Isi perjanjian tersebut dianggap tidak pernah ada dan tidak mengikat para pihak. Majelis hakim kasasi tidak mempertimbangkan sama sekali isi gugatan tentang perjanjian klausula baku yang dimohonkan oleh penggugat untuk dibatalkan dan diseuaikan dengan Pasal 18 Undang-Undang Perlindungan Konsumen. Putusan kasasi justru menilai bahwa Badan Penyelesaian Sengketa Konsumen tidak berwenang memeriksa dan memutus sengketa tersebut karena tidak memenuhi 
kualifikasi sebagai sengketa konsumen;

2. Putusan Nomor 15/PDT.G/2015/PN.SBY dan Putusan Nomor 26/P.BPSK/12/2014 lebih mencerminkan keadilan substantif dan perlindungan terhadap konsumen jika dibandingkan dengan Putusan Nomor 184 K/PDT.SUS-BPSK/2016 karena lebih banyak parameter keadilan substantif yang terpenuhi. Majelis hakim kasasi dalam membuat pertimbangan hukum kurang cermat sehingga putusan yang dihasilkan tidak melindungi konsumen sebagai pihak yang dirugikan dan posisinya lemah. Majelis hakim kasasi seharusnya mempertimbangkan dampak yang muncul dari dibuatnya putusan ini terhadap perlindungan konsumen sebagai pihak yang lemah berhadapan dengan pelaku usaha. Majelis hakim kasasi seharusnya tidak hanya mempertimbangkan dari sisi formal kewenangan Badan Penyelesaian Sengketa Konsumen dalam memeriksa sengketa konsumen sebagaimana diatur oleh Pasal 1 angka 8 Keputusan Menteri Perindustrian Nomor 350/MPP/Kep/12/2001 tentang Pelaksanaan Tugas dan Wewenang Badan Penyelesaian Sengketa Konsumen, sehingga putusannya menganggap bahwa sengketa tersebut bukan sebagai sengketa konsumen yang menjadi kewenangan Badan Penyelesaian Sengketa Konsumen. Jika hanya sisi tersebut maka putusan kasasi menjadi kurang bermakna dilihat dari aspek perlindungan konsumen.

\section{SARAN}

Saran yang dapat diajukan berdasarkan hasil kajian ini adalah bahwa majelis hakim kasasi yang menangani masalah konsumen, seharusnya lebih peka, sensitif, dan peduli terhadap masalah, kepentingan dan hak-hak konsumen sebagaimana diatur dalam Undang-Undang Perlindungan Konsumen.

\section{DAFTAR ACUAN}

Badrulzaman, M. D. (1990). Perjanjian baku (Standar) perkembangannya di Indonesia. Bandung: Alumni.

Barkatullah, A. H. (2008). Hukum perlindungan konsumen (Kajian teoretis \& perkembangan pemikiran). Cetakan pertama. Bandung: Nusa Media.

Fuady, M. (2003). Hukum kontrak (Dari sudut pandang hukum bisnis). Cetakan kedua. Bandung: PT Citra Aditya Bakti.

Jamil, A. (2008). "Cara berhubungan yang benar bagi Profesional hukum (Ijtihad sebagai terobosan hukum progresif)", Jurnal Hukum FH UII, Edisi No. 1 Vol.15, Januari 2008.

Kristiyanti, C. T. S. (2009). Hukum perlindungan konsumen. Cetakan kedua. Jakarta: Sinar Grafika.

Mertokusumo, S. (1990). Mengenal hukum suatu pengantar. Yogyakarta: Liberty.

Miru, A., \& Yodo, S. (2014). Hukum perlindungan konsumen. Jakarta: PT Raja Grafindo Persada.

Muhammad, A. K. (1992). Perjanjian baku dalam praktik perusahaan perdagangan. Bandung: Citra Aditya Bakti.

Rahardjo, R. (2007). Membedah hukum progresif. 
Cetakan kedua. Jakarta: Penerbit Buku Kompas.

Shidarta. (2006). Hukum perlindungan konsumen Indonesia. Jakarta: PT Grasindo.

Siregar, B. (1983). Berbagai segi hukum \& perkembangan dalam masyarakat. Bandung: Alumni.

Sutiyoso, B. (2006). Metode penemuan hukum. Yogyakarta: UII Press.

Syamsudin, M. (2011). Rekonstruksi perilaku etik hakim dalam menangani perkara berbasis hukum progresif. Jurnal Hukum dan Pembangunan, 18, 57-75.

Syamsudin, M. (2014, April). Keadilan prosedural \& substantif dalam putusan sengketa tanah magersari (Kajian Putusan Nomor 74/PDT. G2009/PN.YK). Jurnal Yudisial, 7(1), 75-85.

Tobing, D. M. L (2016, Desember 19). Konsumen \& klausula baku. Diakses dari http://bpkn.go.id/ uploads/document/6ac89beeea3f0dc87095541 b6523952083ebd4dc.pdf.

Wardah, S., \& Sutiyoso, B. (2007). Hukum acara perdata \& perkembangannya di Indonesia. Cetakan pertama. Yogyakarta: Gama Media.

Widjaja, G., \& Yani, A. (2000). Hukum tentang Perlindungan konsumen. Jakarta: Gramedia.

Zulham. (2013). Hukum perlindungan konsumen. Jakarta: PT Kencana Prenada Media Group. 